\title{
Circulatory changes in acute glomerulonephritis at rest and during exercise
}

\author{
Kenan Binak, Necati Sirmaci, Dinçer Uçak, and Nejat Harmanci \\ From the Cardiovascular Research Laboratory, Medical Clinic, Cerrahpasa Medical Faculty, University of \\ Istanbul, Turkey
}

In order to evaluate the effects of acute glomerulonephritis on the circulation, 6 patients were investigated at rest and during moderate exercise. With the patients in a state of rest the cardiac index and the stroke volume index were significantly higher in acute glomerulonephritis than normal, despite significantly raised right and left atrial pressures. Oxygen consumption was significantly increased $(P<0.0 I)$ and the arteriovenous oxygen difference was narrowed significantly $(P<0.001)$ in acute glomerulonephritis as compared to normal subjects. The calculated increase in cardiac output was due to both a rise in oxygen consumption and a narrowing of arteriovenous oxygen difference, the latter being more significant.

The exercise-induced changes in cardiac output in the patients with glomerulonephritis were not different from those in normal subjects.

These results showed that the circulatory changes in the oliguric stage of acute glomerulonephritis resemble those in the hyperkinetic states; the raised mean right atrial and pulmonary wedge pressures do not indicate the presence of heart failure when resting cardiac output is above normal level and response to exercise is normal.

The manifestations of circulatory congestion encountered in the oliguric phase of acute glomerulonephritis are considered by some authors (Wilson, 1967; Gore and Saphir, 1948; Master, Jaffe, and Dack, 1937; Whitehill, Longcope, and Williams, 1939) to be an expression of heart failure. On the other hand, Davies (195I) and Eichna et al. (1954) stressed that the syndrome suggesting heart failure seen in acute glomerulonephritis was an extracardiac circulatory congestion caused by water and salt retention.

Haemodynamic studies in acute glomerulonephritis have revealed that performance of the heart as a pump is not impaired. Davies (I95I) and Eichna et al. (I954) reported normal values for cardiac output and stroke volume at rest. DeFazio et al. (1959) found that cardiac output and stroke volume were raised despite high right and left atrial pressures at rest.

Circulatory changes during exercise in acute glomerulonephritis have not yet been investigated thoroughly. DeFazio et al. (1959) found normal response to exercise in one patient and Guz et al. (1966) found the slope of the cardiac output/oxygen

Received II February I975. consumption relation to be increased during exercise in one of his patients.

Since it is known that the evaluation of cardiac performance requires exercise data, it was considered that haemodynamic response to exercise in acute glomerulonephritis would provide additional information concerning myocardial function in this particular syndrome. These considerations form the background of this haemodynamic study in 6 patients with acute glomerulonephritis.

\section{Subjects and methods}

Studies were made of 6 patients with typical clinical and laboratory findings of post-streptococcal acute glomerulonephritis and of 6 normal subjects as controls. Informed consent for the study was obtained from the patients as well as from the control group. The important clinical and laboratory findings in the patients with acute glomerulonephritis are shown in Tables $I$ and 2. All the patients were male, ranging in age from 14 to 24 years. Patients were studied before the onset of natural diuresis. As a result of diuresis patients lost about 2 to $6 \mathrm{~kg}$ in the days after the haemodynamic study. Pyrexia was not present in any of the patients. All cases had palpebral and 3 cases also had pretibial pitting oedema (Cases I, 5, and 6). Six patients had dyspnoea, 4 patients 
TABLE I Clinical findings*

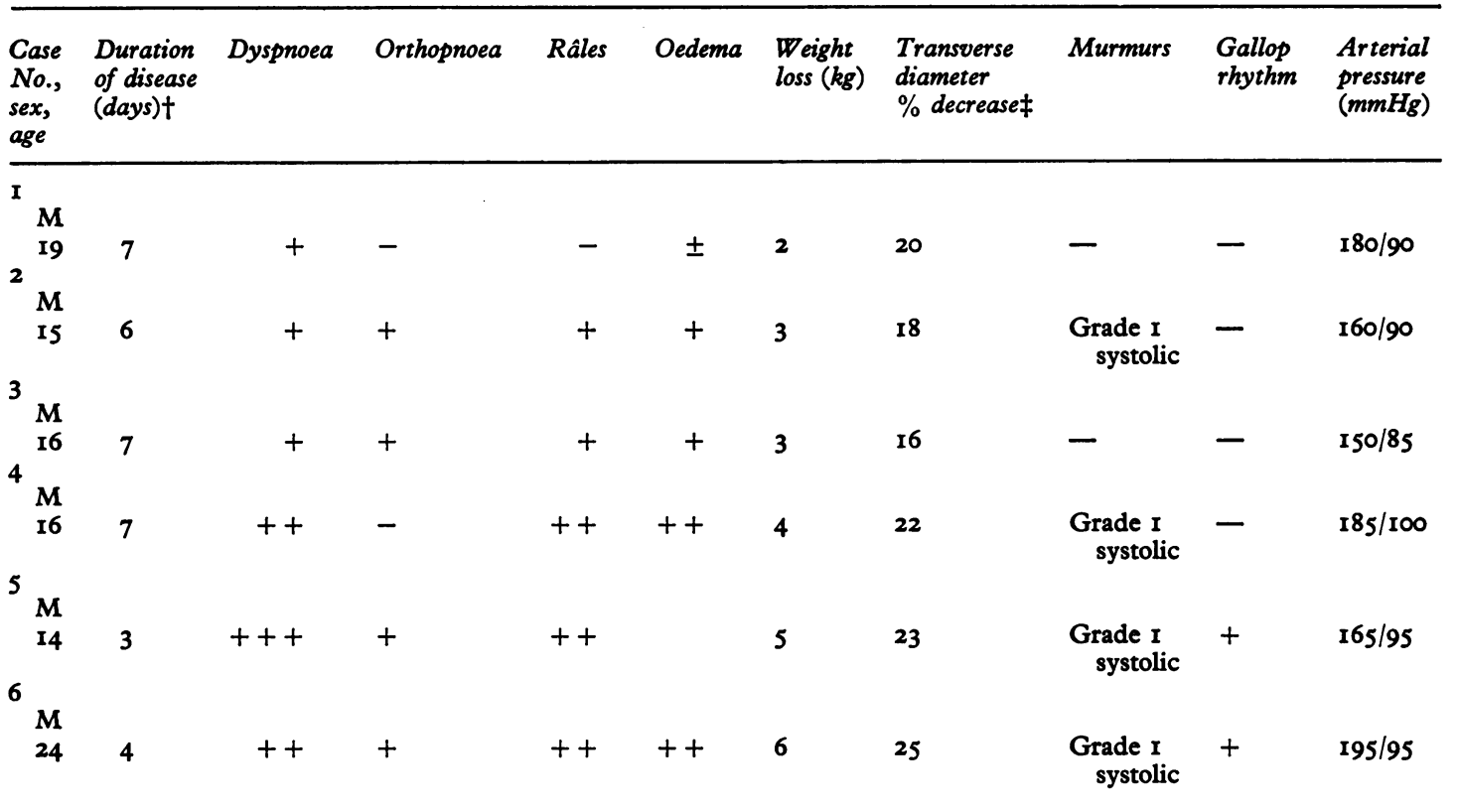

Conversion factor from Traditional to SI Units: I mmHg $\approx 0.133 \mathrm{kPa} ; \mathrm{cmH}_{2} 0 \approx 0.98 \mathrm{kPa}$.

$\star$ Most of the clinical findings are graded on a scale of + to ++++ .

t Duration of the disease when catheterization was performed.

$¥$ Decrease of the transverse diameter of the heart after natural diuresis.

had mild orthopnoea, and 2 patients had apical diastolic gallop rhythm $\left(S_{3}\right)$. Pulmonary basal râles were heard in 5 patients, jugular venous pressure was increased in all patients, and the circulation time was in the normal range before the study. The transverse diameter of the heart was increased in all patients during the oliguric phase. After diuresis transverse diameters of the heart decreased appreciably, the mean decrease being 2 I per cent. Transverse diameter of the heart was measured on standard 6 foot posteroanterior chest films of the patients before and after diuresis was initiated. Slight to moderate arterial hypertension was present and urinary findings consisted of + to ++ albumin, and red blood cells; some of the patients had cylindruria. Blood urea nitrogen concentrations were between 39.3 and 74.9 $\mathrm{mmol} / \mathrm{l}$ (55 and $105 \mathrm{mg} / \mathrm{dl}$ ) in the patients. The total serum protein level was normal in 3 and at lower limits in 3 cases and serum albumin ranged between 30 to 40 g/l. Plasma sodium levels were within normal limits in all cases, plasma potassium level being slightly raised in one case.

Right heart catheterization was performed on the

TABLE 2 Laboratory findings

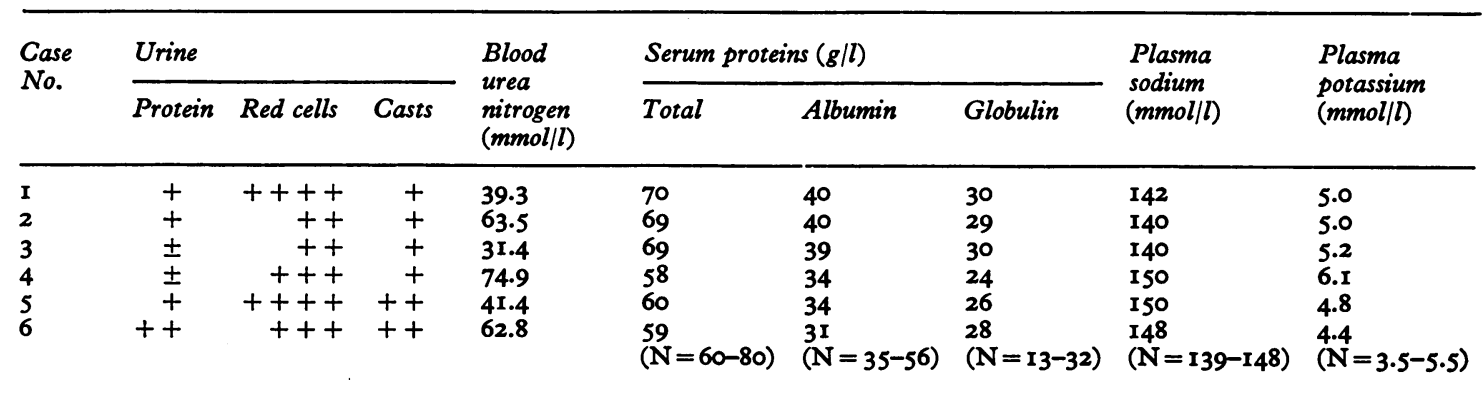

N normal range. 


\begin{tabular}{ll}
\hline $\begin{array}{l}\text { Venous } \\
\text { pressure } \\
\left(\mathrm{cmH}_{2} \mathrm{O}\right)\end{array}$ & $\begin{array}{l}\text { Circulation } \\
\text { time }(s)\end{array}$ \\
\hline 14 & 10 \\
16 & 13 \\
20 & 12 \\
20 & 10 \\
20 & 12 \\
\end{tabular}

normal subjects and patients in the overnight fasting state, and to obtain a reasonable sedation 50 to $100 \mathrm{mg}$ pethidine ('demerol') was given one hour before the start of the procedure. A double lumen catheter was employed; the distal opening was wedged in a branch of the pulmonary artery in order to obtain pulmonary wedge pressure and the proximal opening was in the pulmonary artery. An indwelling Cournand needle was placed in the brachial artery to obtain arterial pressures and blood samples.

Cardiac outputs were determined by the direct Fick principle (Fick, 1870). Measurement of cardiac output by the oxygen Fick method can sometimes be in error by more than I0O per cent. This, however, is not caused by any basic error in the principle itself, but instead by misapplication of the principle (Guyton, 1963; Visscher and Johnson, I953). The types of errors involved can be classified into three categories: $I$ ) errors in sampling and analysis; 2) errors caused by unstable cardiac outputs; 3 ) errors caused by a changing respiratory condition.

To minimize the potential errors in the measurement of cardiac output which are listed above, the following method was applied. Oxygen consumption was determined by analysis of expired air which was collected in a Tissot spirometer and of room air for oxygen content on a Pauling oxygen analyser. During the collection of expired air, blood samples were slowly and simultaneously withdrawn under oil from the brachial artery and the pulmonary artery, and their oxygen content, capacity, and saturation were determined in duplicate, errors being less than 0.2 per cent vol. $\mathrm{O}_{2}$, by the method of Van Slyke and Neill (I924) and Peters and Van Slyke (1943). Immediately after the determination of cardiac output, simultaneous pulmonary arterial and brachial arterial pressures were recorded by a Sanborn strain gauge transducer and photographic writing polyviso (Electronics for Medicine). The zero reference point for supine position was taken as the midpoint of the anteroposterior diameter of the chest at the level of the third interspace at the sternum. Mean pressures were obtained by electrical integration.

After observations at rest, haemodynamic response to moderate exercise was studied. Higher and repeated work loads were not attempted in order to avoid the potential risk of dyspnoea which can initiate anxiety, resulting in changes in cardiac output. Exercise studies involved pedalling a bicycle ergometer in the recumbent position at a rate of 60 revolutions per minute at the same load ( 50 watts) for 5 minutes, all parameters being measured during the last minute of exercise. From the results the following calculations were made:

Total peripheral resistance in dynes $\mathrm{s} \mathrm{cm}^{-5}=$

$$
\frac{\mathrm{BAm} \times 1332}{\mathrm{CO}}
$$

Pulmonary arteriolar resistance in dynes $\mathrm{s} \mathrm{cm}^{-5}=$

$$
\frac{(\text { PAm-PWm) } \times 1332}{\mathrm{CO}}
$$

Left ventricular work index in $\mathrm{kg} \mathrm{m} / \mathrm{min}$ per $\mathrm{m}^{2} \mathrm{BSA}=$

$$
\frac{\mathrm{CI} \times 1.055 \times(\mathrm{BAm}-\mathrm{PWm}) \times 13.6}{1000}
$$

Right ventricular work index in $\mathrm{kg} \mathrm{m} / \mathrm{min}$ per $\mathrm{m}^{2} \mathrm{BSA}=$

$$
\frac{\mathrm{CI} \times 1.055 \times(\mathrm{PAm}-\mathrm{RAm}) \times 13.6}{1000}
$$

Where: $\mathbf{B A m}=$ mean brachial artery pressure in $\mathrm{mmHg} ; \mathrm{PAm}=$ mean pulmonary artery pressure in mmHg; $\mathrm{PWM}=$ mean pulmonary artery wedge pressure in $\mathrm{mmHg} ; \mathrm{RAm}=$ mean right atrial pressure in $\mathrm{mmHg} ; \mathrm{CO}=$ cardiac output in $\mathrm{ml}$ per second; $\mathrm{CI}=$ cardiac index in litre/min per $\mathrm{m}^{2} \mathrm{BSA} ; \mathbf{r} 332=$ conversion factor for $\mathrm{mmHg}$ to dynes $/ \mathrm{cm}^{2}$; $1055=$ specific gravity of blood and $13.6=$ specific gravity of mercury.

For statistical evaluation of the haemodynamic results at rest, data obtained from patients with acute glomerulonephritis have been compared with those obtained from normal subjects. For each resting haemodynamic parameter, the significance of the difference between the means of normal and acute glomerulonephritis patients has been evaluated by the utilization of the $t$ test (Schwartz and Lazar, 1964).

Response to exercise was evaluated by comparing the percentage changes in pre-exercise and post-exercise values for normal subjects with those for patients with acute glomerulonephritis. 
TABLE 3 Haemodynamic changes at rest and during exercise in normal subjects

\begin{tabular}{|c|c|c|c|c|c|c|c|c|c|c|c|c|}
\hline \multirow{2}{*}{$\begin{array}{l}\text { Case No., } \\
\text { sex, age }\end{array}$} & & \multirow{2}{*}{$\begin{array}{l}\text { Body } \\
\text { surface } \\
\text { area } \\
\left(m^{2}\right)\end{array}$} & \multirow{2}{*}{$\begin{array}{l}\mathrm{O}_{2} \\
\text { consumption } \\
\text { (ml/min per } \\
\left.m^{2} B S A\right)\end{array}$} & \multirow{2}{*}{$\begin{array}{l}\mathrm{O}_{2} \\
A V \\
\text { difference } \\
(\mathrm{ml} / \mathrm{l})\end{array}$} & \multirow{2}{*}{$\begin{array}{l}\text { Cardiac } \\
\text { index } \\
(l / \text { min per } \\
m^{2} \\
B S A)\end{array}$} & \multirow{2}{*}{$\begin{array}{l}\text { Heart } \\
\text { rate }\end{array}$} & \multirow{2}{*}{$\begin{array}{l}\text { Stroke } \\
\text { index } \\
\text { (ml/beat per } \\
\left.m^{2} B S A\right)\end{array}$} & \multicolumn{4}{|c|}{ Mean pressure $(\mathrm{mmHg})$} & \multirow{2}{*}{$\begin{array}{l}\begin{array}{l}\text { Resistance } \\
\text { dynes } 5 \mathrm{~cm}^{-\mathrm{B}}\end{array} \\
\begin{array}{l}\text { Total } \\
\text { peripheral }\end{array}\end{array}$} \\
\hline & & & & & & & & $B A$ & $P A$ & $P W$ & $R A$ & \\
\hline \multirow{2}{*}{ I, F. 25} & $\mathbf{R}$ & r.69 & 140 & 35 & 4.00 & 92 & 43 & 92 & 16 & 7 & 3 & 1090 \\
\hline & $\mathbf{E}$ & & 240 & 45 & 5.33 & 118 & 45 & 95 & 17 & 9 & 4 & 844 \\
\hline \multirow{2}{*}{$2, F, 25$} & $\bar{R}$ & 1.69 & I 40 & 38 & 3.69 & 95 & 39 & 102 & 17 & 6 & 4 & 963 \\
\hline & $\mathrm{E}$ & & 230 & 46 & 5.00 & 134 & 38 & I II & 19 & 8 & 4 & 1048 \\
\hline \multirow{3}{*}{$3, M, 20$} & $\mathbf{R}$ & 1.62 & 200 & 40 & 5.00 & 80 & 60 & 100 & 18 & 7 & 4 & 990 \\
\hline & $E$ & & 380 & 50 & 7.60 & 96 & 80 & 106 & 20 & 9 & 3 & 685 \\
\hline & $\mathbf{R}$ & I.59 & 198 & 39 & 5.08 & 88 & 58 & 80 & 18 & 7 & 2 & 789 \\
\hline \multirow{2}{*}{$4, M, 30$} & $\mathbf{E}$ & & 374 & 57 & 6.56 & 102 & 64 & 84 & 18 & Io & 3 & 643 \\
\hline & $\mathbf{R}$ & I.56 & 170 & 38 & 4.47 & 89 & 50 & 93 & 17 & 7 & 3 & 1068 \\
\hline $5, M, 22$ & E & & 301 & 52 & 6.00 & II2 & 54 & 99 & 19 & 9 & 4 & 809 \\
\hline \multirow{2}{*}{$6, M, 24$} & $\mathbf{R}$ & I. 50 & 150 & 42 & 3.57 & 70 & 51 & 92 & 17 & 6 & 3 & 1360 \\
\hline & $E$ & & 270 & 50 & 5.40 & 90 & 60 & 98 & 19 & 8 & 4 & 816 \\
\hline \multirow{2}{*}{ Mean } & $\mathbf{R}$ & I.6I & 166 & 39 & $4 \cdot 30$ & 86 & 50 & 93 & 17 & 7 & 3 & 1043 \\
\hline & E & & 299 & 50 & 5.98 & 109 & 57 & 99 & 19 & 9 & 4 & 808 \\
\hline
\end{tabular}

Conversion factor from Traditional to SI units: $1 \mathrm{mmHg} \approx 0.133 \mathrm{kPa} ; 10$ dynes $\mathrm{s} \mathrm{cm}^{-5} \approx \mathrm{IMPa} \mathrm{s} \mathrm{m}{ }^{-3}$.

TABLE 4 Haemodynamic changes at rest and during exercise in patients with acute glomerulonephritis

\begin{tabular}{|c|c|c|c|c|c|c|c|c|c|c|c|}
\hline \multirow{2}{*}{$\begin{array}{l}\text { Case No., } \\
\text { sex, age }\end{array}$} & \multirow{2}{*}{$\begin{array}{l}\text { Body } \\
\text { surface } \\
\text { area } \\
\left(m^{2}\right)\end{array}$} & \multirow{2}{*}{$\begin{array}{l}\mathrm{O}_{2} \\
\text { consumption } \\
\text { (ml/min per } \\
\left.m^{2} B S A\right)\end{array}$} & \multirow{2}{*}{$\begin{array}{l}\mathrm{O}_{2} \\
\mathrm{AV} \\
\text { difference } \\
(\mathrm{ml} / \mathrm{l})\end{array}$} & \multirow{2}{*}{$\begin{array}{l}\text { Cardiac } \\
\text { index } \\
(l / \min \text { per } \\
m^{2} \\
B S A)\end{array}$} & \multirow{2}{*}{$\begin{array}{l}\text { Heart } \\
\text { rate }\end{array}$} & \multirow{2}{*}{$\begin{array}{l}\text { Stroke } \\
\text { index } \\
\text { (ml/beat per } \\
\left.m^{2} B S A\right)\end{array}$} & \multicolumn{4}{|c|}{ Mean pressure $(\mathrm{mmHg})$} & \multirow{2}{*}{$\begin{array}{l}\begin{array}{l}\text { Resistance } \\
\text { dynes } \mathrm{s} \mathrm{cm}^{-\mathrm{s}}\end{array} \\
\begin{array}{l}\text { Total } \\
\text { peripheral }\end{array}\end{array}$} \\
\hline & & & & & & & $B A$ & $P A$ & $P W$ & $R A$ & \\
\hline \multirow{2}{*}{$\mathbf{I}, \mathbf{M}, \mathbf{I} 9$} & $\begin{array}{ll}1.50 \\
R\end{array}$ & I44 & 30 & 4.80 & 75 & 55 & 125 & 20 & 13 & 6 & 1386 \\
\hline & & 240 & $4 \mathrm{I}$ & 5.85 & 90 & 65 & 135 & 22 & 16 & 6 & 1225 \\
\hline \multirow{2}{*}{$2, M, 15$} & 1.39 & I94 & 35 & 5.54 & 80 & 69 & 120 & 22 & 13 & 6 & 1245 \\
\hline & & 400 & 50 & 8.00 & 95 & 84 & 128 & 24 & 16 & 5 & 922 \\
\hline \multirow{2}{*}{ 3, M, I6 } & $\begin{array}{ll}1.36 \\
2.03\end{array}$ & 160 & 34 & $4.7 \mathrm{I}$ & 100 & 40 & IIO & 22 & 16 & 4 & I344 \\
\hline & & 316 & 50 & 6.32 & 115 & $5 \mathrm{I}$ & I16 & 24 & 19 & 4 & 1081 \\
\hline \multirow{3}{*}{ 4, M, I6 } & $\begin{array}{ll}1.50 \\
2.50\end{array}$ & 180 & 34 & 5.30 & 52 & 89 & 140 & 25 & 14 & 7 & 1402 \\
\hline & & 340 & 47 & 7.23 & 71 & IOI & 155 & 26 & 18 & 8 & II4I \\
\hline & 1.20 & 217 & 34 & 6.38 & 70 & 91 & 118 & 20 & 15 & 8 & 1228 \\
\hline $5, M, I 4$ & & 416 & 44 & 9.45 & 94 & 100 & 120 & 24 & 18 & 9 & 846 \\
\hline \multirow{2}{*}{$6, M, 24$} & $\begin{array}{ll}2 & 1.60\end{array}$ & 190 & 35 & 5.43 & 100 & 54 & 120 & 24 & 16 & 8 & IIO2 \\
\hline & 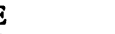 & 382 & 44 & 8.00 & 120 & 67 & 130 & 26 & 18 & I0 & 813 \\
\hline \multirow{2}{*}{ Mean } & 1.42 & $18 \mathrm{I}$ & 34 & 5.36 & 80 & 66 & 122 & 22 & 15 & 6 & 1284 \\
\hline & 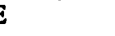 & 349 & 46 & 7.48 & 98 & 78 & I3I & 24 & 18 & 7 & 1005 \\
\hline
\end{tabular}

Conversion factor from Traditional to SI units: I mmHg $\approx 0.133 \mathrm{kPa} ; 10$ dynes $\mathrm{s} \mathrm{cm}^{-5} \approx \mathrm{IMPa} \mathrm{s} \mathrm{m}{ }^{-3}$.

\section{Results}

The haemodynamic data in normal subjects and in patients with acute glomerulonephritis at rest and during exercise are presented in Tables 3 and 4, respectively. Table 5 shows the mean values in normal subjects and patients and the $P$ values of the difference of the means. Haemodynamic changes during exercise in normal subjects and in acute glomerulonephritis are presented in Table 6.

With the patients at rest, the cardiac index was higher than the highest value of normal subjects in
3 patients, with a range from $4.7 \mathrm{I}$ to $6.38 \mathrm{l} / \mathrm{min}$ per $\mathrm{m}^{2}$ BSA. The mean of the patient group was $5.36 \mathrm{l} / \mathrm{min}$ per $\mathrm{m}^{2} \mathrm{BSA}$ compared with the normal mean of $4.301 / \mathrm{min}$ per $\mathrm{m}^{2} \mathrm{BSA}$. The difference is significant at a level of less than 2 per cent. Exerciseinduced changes in cardiac index were similar in normal subjects and in patients with glomerulonephritis, the mean increment being 39 per cent and 40 per cent, respectively.

Oxygen consumption in patients at rest was significantly increased at a level of less than I per cent; it 


\begin{tabular}{|c|c|c|}
\hline \multirow[b]{2}{*}{$\begin{array}{l}\text { Pulmonary } \\
\text { arteriolar }\end{array}$} & \multicolumn{2}{|c|}{$\begin{array}{l}\text { Work index } \\
\left(\mathrm{kg} \mathrm{m} / \mathrm{min} \text { per } \mathrm{m}^{2} B S A\right)\end{array}$} \\
\hline & $\begin{array}{l}\text { Left } \\
\text { ventricular }\end{array}$ & $\begin{array}{l}\text { Right } \\
\text { ventricular }\end{array}$ \\
\hline ro7 & 4.86 & 0.74 \\
\hline 71 & 5.12 & 0.99 \\
\hline I52 & 5.07 & 0.69 \\
\hline 104 & 7.36 & 1.07 \\
\hline 108 & 6.65 & 1.00 \\
\hline 71 & 10.54 & 1.85 \\
\hline 88 & 5.30 & I.I4 \\
\hline $6 r$ & 6.94 & $1.4 \mathrm{I}$ \\
\hline 115 & 5.50 & 0.95 \\
\hline 82 & 7.72 & 1.29 \\
\hline 160 & 4.39 & 0.71 \\
\hline 91 & 6.95 & I.16 \\
\hline 122 & 5.30 & 0.87 \\
\hline 80 & 7.44 & 1.29 \\
\hline
\end{tabular}

\begin{tabular}{|c|c|c|}
\hline \multirow[b]{2}{*}{$\begin{array}{l}\text { Pulmonary } \\
\text { arteriolar }\end{array}$} & \multicolumn{2}{|c|}{$\begin{array}{l}\text { Work index } \\
\left(\mathrm{kg} \mathrm{m} / \mathrm{min} \text { per } \mathrm{m}^{2} \mathrm{BSA}\right)\end{array}$} \\
\hline & $\begin{array}{l}\text { Left } \\
\text { ventricular }\end{array}$ & $\begin{array}{l}\text { Right } \\
\text { ventricular }\end{array}$ \\
\hline 78 & 7.68 & 0.96 \\
\hline $\begin{array}{l}55 \\
94\end{array}$ & $\begin{array}{l}9.95 \\
8.50\end{array}$ & $\begin{array}{l}1.33 \\
1.27\end{array}$ \\
\hline 58 & 12.86 & 2.17 \\
\hline 46 & 6.33 & 1.22 \\
\hline 40 & 8.76 & I.8I \\
\hline $\begin{array}{r}113 \\
80\end{array}$ & $\begin{array}{r}9.55 \\
14.16\end{array}$ & $\begin{array}{l}1.36 \\
1.86\end{array}$ \\
\hline 50 & 10.34 & I.10 \\
\hline 42 & 13.88 & 2.03 \\
\hline 70 & 8.10 & 1.24 \\
\hline 50 & 12.86 & 2.06 \\
\hline 75 & 8.42 & r.19 \\
\hline 54 & I I.97 & I.88 \\
\hline
\end{tabular}

averaged $\mathrm{I} 8 \mathrm{I} \mathrm{ml} / \mathrm{min}$ per $\mathrm{m}^{2} \mathrm{BSA}$ with a range of 144 to $217 \mathrm{ml} / \mathrm{min}$ per $\mathrm{m}^{2} \mathrm{BSA}$, as compared to the normal mean of $166 \mathrm{ml} / \mathrm{min}$ per $\mathrm{m}^{2}$ BSA. Arteriovenous oxygen difference were narrowed significantly $(P<0.00 r)$ in all patients, ranging from 30 to $35 \mathrm{ml}$ per litre. During exercise oxygen consumption increased and arteriovenous oxygen difference widened in acute glomerulonephritis, the average changes being 93 and 35 per cent, respectively. In normals the average changes in these measurements were 80 and 28 per cent, respectively.
Pulse rates were generally within normal limits, with a range of 52 to 100 per minute in acute glomerulonephritis and they increased 23 per cent during exercise. In normals the increase was 27 per cent.

The stroke volume index was significantly greater than normal $(P<0.02)$, the mean stroke volume index for the acute glomerulonephritis being $66 \mathrm{ml}$ per beat per $\mathrm{m}^{2} \mathrm{BSA}$, as compared to the normal mean of $50 \mathrm{ml}$ per beat per $\mathrm{m}^{2}$ BSA. Stroke volume index increased 14 per cent in normals and 19 per cent in patients during exercise.

The pulmonary wedge pressures were significantly raised in all patients $(P<0.001)$, ranging from 13 to $16 \mathrm{mmHg}$ ( 1.7 to $2.1 \mathrm{kPa}$ ), with a mean of $15 \mathrm{mmHg}(2.0 \mathrm{kPa})$, as compared to the normal mean of $7 \mathrm{mmHg}(0.9 \mathrm{kPa})$. The same significant increase $(\mathbf{P}<0.001)$ was observed in right atrial pressure in all patients except one (Case 3), ranging from 4 to $8 \mathrm{mmHg}$ ( 0.5 to $1.1 \mathrm{kPa}$ ), with a mean of $6 \mathrm{mmHg}(0.8 \mathrm{kPa})$, as compared to the normal subjects. Both pulmonary capillary wedge and right atrial mean pressures were raised during exercise, the increment being 29 per cent and 33 per cent in normal subjects and 20 per cent and 17 per cent in acute glomerulonephritis, respectively.

Significant increase in the pulmonary artery mean pressure was observed in all patients with a mean of $22 \mathrm{mmHg}(2.9 \mathrm{kPa})$, as compared to the normal mean of $17 \mathrm{mmHg}(2.7 \mathrm{kPa})$. In the patients, the brachial arterial mean pressures ranged from 120 to $140 \mathrm{mmHg}$ ( 16.0 to $18.6 \mathrm{kPa}$ ), with a mean of $122 \mathrm{mmHg}(16.2 \mathrm{kPa})$, which is significantly higher than the normal mean of $93 \mathrm{mmHg}$ (12.4 $\mathrm{kPa})(\mathbf{P}<0.00 \mathrm{r})$. Both left and right ventricular work indices were significantly higher than normal $(\mathrm{P}<0.00 \mathrm{r})$. The calculated total peripheral resistance was significantly higher than normal $(P<0.00 I)$, and pulmonary arteriolar resistance was lower than normal $(\mathbf{P}<0.02)$. In both groups, pulmonary and brachial arterial pressures, and left and right ventricular work indices increased while total peripheral and pulmonary arteriolar resistance decreased appreciably during exercise.

\section{Discussion}

A particular haemodynamic pattern has been observed in our cases of acute glomerulonephritis: a high cardiac output and stroke volume, a reduced arteriovenous oxygen difference, a normal to high oxygen consumption, raised left and right atrial pressures, a high total peripheral resistance, a normal to low pulmonary arteriolar resistance, and high systemic arterial and pulmonary arterial pressures 
TABLE 5 Mean values in normal subjects and patients with glomerulonephritis at rest

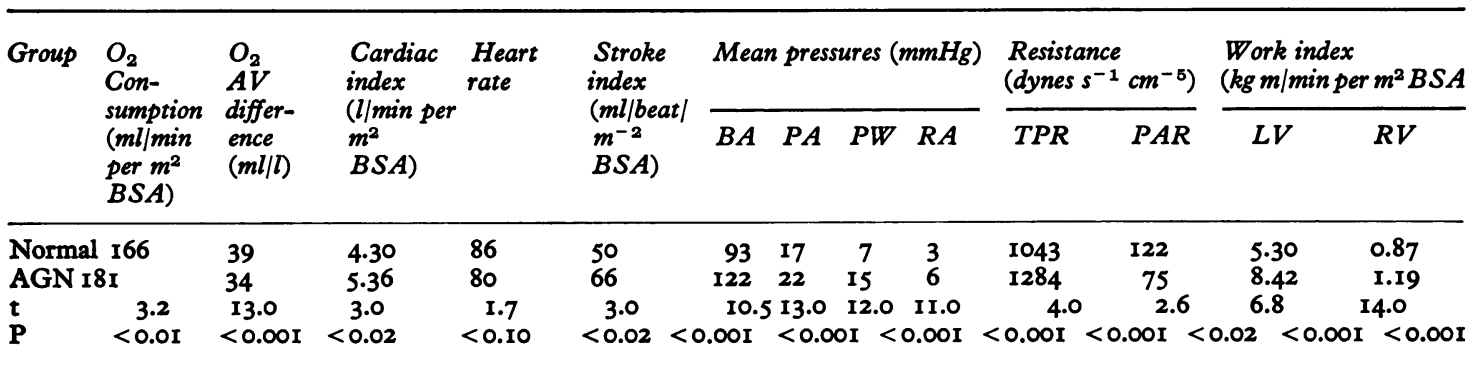

BA, brachial artery; PA, pulmonary artery; PW, pulmonary artery wedge; RA, right atrium; TPR, total peripheral resistance; PAR, pulmonary arteriolar resistance; $L V$, left ventricular; $R V$, right ventricular; $A G N$, acute glomerulonephritis.

Conversion from Traditional to SI units: I $\mathrm{mmHg} \approx 0.133 \mathrm{kPa}$; 10 dynes $\mathrm{s} \mathrm{cm}^{-5} \approx \mathrm{I} \mathrm{MPa} \mathrm{s} \mathrm{m} \mathrm{m}^{-3}$.

TABLE 6 Haemodynamic changes at rest and during exercise in normal subjects and in patients with acute glomerulonephritis (mean values)

\begin{tabular}{|c|c|c|c|c|c|c|c|c|c|c|}
\hline \multirow[t]{2}{*}{ Group } & \multirow{2}{*}{$\begin{array}{l}\text { Experimental } \\
\text { condition }\end{array}$} & \multirow{2}{*}{$\begin{array}{l}\mathrm{O}_{2} \\
\text { consump- } \\
\text { tion } \\
(\mathrm{ml} / \mathrm{min} \\
\text { per } \mathrm{m}^{2} \\
B S A)\end{array}$} & \multirow{2}{*}{$\begin{array}{l}\mathrm{O}_{2} \\
A V \\
\text { difference } \\
(\mathrm{ml} / \mathrm{l})\end{array}$} & \multirow{2}{*}{$\begin{array}{l}\text { Cardiac } \\
\text { index } \\
(l / m i n \\
\left.m^{2} B S A\right)\end{array}$} & \multirow{2}{*}{$\begin{array}{l}\text { Heart } \\
\text { rate }\end{array}$} & \multirow{2}{*}{$\begin{array}{l}\text { Stroke } \\
\text { index } \\
\text { (mllbeat per } \\
\left.m^{2} B S A\right)\end{array}$} & \multicolumn{4}{|c|}{ Mean pressures $(\mathrm{mmHg})$} \\
\hline & & & & & & & $B A$ & $P A$ & $P W$ & $R A$ \\
\hline $\begin{array}{l}\text { Normal } \\
\% \text { change } \\
\text { Acute } \\
\text { glomerulonephritis } \\
\% \text { change }\end{array}$ & $\begin{array}{l}\mathbf{R} \\
\mathbf{E} \\
\mathbf{R} \\
\mathbf{E}\end{array}$ & $\begin{array}{r}166 \\
299 \\
+80 \\
181 \\
349 \\
+93\end{array}$ & $\begin{array}{r}39 \\
50 \\
+28 \\
34 \\
46 \\
+35\end{array}$ & $\begin{array}{l}4.30 \\
5.98 \\
+39 \\
5.36 \\
7.48 \\
+40\end{array}$ & $\begin{array}{r}86 \\
109 \\
+27 \\
80 \\
98 \\
+23\end{array}$ & $\begin{array}{r}50 \\
57 \\
+14 \\
66 \\
78 \\
+19\end{array}$ & $\begin{array}{r}93 \\
99 \\
+60 \\
122 \\
131 \\
+8\end{array}$ & $\begin{array}{r}17 \\
19 \\
+12 \\
22 \\
24 \\
+9\end{array}$ & $\begin{array}{r}7 \\
9 \\
+29 \\
15 \\
18 \\
+20\end{array}$ & $\begin{array}{r}3 \\
4 \\
+33 \\
6 \\
+17\end{array}$ \\
\hline
\end{tabular}

Conversion from Traditional to SI units: $1 \mathrm{mmHg} \approx 0.133 \mathrm{kPa}$; 10 dynes $\mathrm{s} \mathrm{cm}^{-5} \approx \mathrm{I} \mathrm{MPa} \mathrm{s} \mathrm{m}{ }^{-3}$.

at rest. This is in accord with the observations of Guz et al. (1966), Bradley, Jenkins, and Branthwaite (197I), and DeFazio et al. (1959). The supernormal response to exercise, alleged to exist in some of the hyperkinetic states, was not observed in our cases. This finding conflicts with the findings of Guz et al. (1966) who found that 'cardiac output was high for the prevailing oxygen consumption in one case of acute glomerulonephritis during exercise.

This high cardiac output at rest and normal response to exercise places these patients in the group of hyperkinetic states which includes patients with chronic anaemia, hyperthyroidism, and chronic arteriovenous fistula. Since none of these diseases was present in our cases, it is supposed that hypervolaemia caused by salt and water retention, which occurs in most patients in the oliguric stage of acute glomerulonephritis (Eichna, 1960; Eisenberg, 1958; Cardozo, 1946), is responsible for the hyperkinetic state.

Right atrial mean pressure and pulmonary wedge mean pressure were raised to a level which was not high enough to produce signs and symptoms of pulmonary congestion and peripheral oedema. But the low serum albumin concentration observed in our 3 cases, together with salt and water retention, might have contributed to the development of pulmonary congestion and peripheral oedema, in spite of relatively low values for left and right atrial pressures.

Increased ventricular end-diastolic pressures, in the face of the high cardiac output at rest, cannot be regarded as evidence in these patients that they were in heart failure. But, according to Guz et al. (1966), high cardiac output at rest does 
not necessarily indicate that the heart is functioning normally and the reserve capacity of the heart should be tested with exercise. When the mean pulmonary wedge pressures were related to stroke volume index it was seen that stroke volume increased more than the pulmonary wedge pressure on exercise as compared to normal subjects. Since in each of our cases the pulmonary wedge pressure was not related to the stroke volume, an increase in the latter could be explained either by an increase in diastolic volume without change in pulmonary wedge pressure or by a more complete emptying of the ventricles because of the increased ventricular contractility. The increase in cardiac size during the oliguric phase and its decrease after natural diuresis or after frusemide injection (Santibenez, Rosendo, and Atherton, 197I) suggest that the diastolic volume is increased in acute glomerulo-

\begin{tabular}{|c|c|}
\hline $\begin{array}{l}\text { Resistance } \\
\text { (dynes } \mathrm{cm}^{-5} \text { ) }\end{array}$ & $\begin{array}{l}\text { Work index } \\
\left(\mathrm{kg} \mathrm{m} / \mathrm{min} \text { per } \mathrm{m}^{2} B S A\right)\end{array}$ \\
\hline
\end{tabular}

\begin{tabular}{lccl}
\hline $\begin{array}{l}\text { Total } \\
\text { peripheral }\end{array}$ & $\begin{array}{l}\text { Pulmonary } \\
\text { arteriolar }\end{array}$ & $\begin{array}{l}\text { Left } \\
\text { ventricular }\end{array}$ & $\begin{array}{l}\text { Right } \\
\text { ventricular }\end{array}$ \\
\hline 1043 & 122 & 5.30 & 0.87 \\
808 & 80 & 7.44 & 1.29 \\
-22 & -34 & +40 & +48 \\
1284 & 75 & 8.42 & 1.19 \\
1005 & 54 & 11.97 & 1.88 \\
-22 & -28 & +42 & +58 \\
\hline
\end{tabular}

nephritis. Since contractility of the ventricles was not measured in this series, it is a matter of conjecture as to whether or not an increase in contractility, during rest and exercise, contributed to the increase in cardiac output.

When the overall results obtained in our cases were evaluated, it was clearly seen that the circulatory changes in acute glomerulonephritis resembled those in hyperkinetic states and the increase in atrial pressures did not indicate the presence of heart failure when resting cardiac output was above normal level and response to exercise was normal.

\section{References}

Bradley, R. D., Jenkins, B. S., and Branthwaite, M. A. (1971). Myocardial function in acute glomerulonephritis. Cardiovascular Research, 5, 223.

Cardozo, E. L. (1946). Hydremia in acute nephritis. Acta Medica Scandinavica, 125, 333.

Davies, C. E. (195I). Heart failure in acute nephritis. Quarterly fournal of Medicine, 20, 163.

DeFazio, V., Christensen, R. C., Regan, T. J., Baer, L. J., Morita, Y., and Hellems, H. K. (1959). Circulatory changes in acute glomerulonephritis. Circulation, 20, 190.

Eichna, L. W. (1960). Circulatory congestion and heart failure. Circulation, 22, 864 .

Eichna, L. W., Farber, S. J. Berger, A. R., Rader, B., Smith, W. W., and Albert, R. E. (1954). Non-cardiac circulatory congestion simulating congestive heart failure. Transactions of the Association of American Physicians, 67, 72.

Eisenberg, S. (1958). The hypervolemia syndrome associated with acute glomerulonephritis. Clinical Research, 6, 292.

Fick, A. (1870). U'ber die messung des blutguantusm in den herzenventrikeln Sitzungsb. Phys. Med. Gessel zu Wurzburg, July, p. I6.

Gore, I., and Saphir, O. (1948). Myocarditis associated with acute and subacute glomerulonephritis. American Heart fournal, 36, 390.

Guyton, A. C. (1963). Circulatory Physiology: Cardiac Output and its Regulation, pp. 30-31. W. B. Saunders, Philadelphia.

Guz, A., Noble, M. I. M., Trenchard, D., Garnett, E. S., Clarkson, E. M., McDonald, S. J., and Wardener, H. E. de (1966). The significance of a raised central venous pressure during sodium and water retention. Clinical Science, 30, 295.

Master, A. M., Jaffe, H. L., and Dack, S. (1937). The heart in acute nephritis. Archives of Internal Medicine, 60, 1016.

Peters, J. R., and Van Slyke, D. D. (1943). Quantitative Clinical Chemistry (Methods), vol. 2. Williams Wilkins, Baltimore.

Santibenez, G. S., Rosendo, R. V., and Atherton, D. S. (1971). Efficacio de la furosemida endovenosa en la etope inicial de la glomerulonephritis aguda post-estreptococcica. Archivos de Investigacion Medica (Mexico), 2, II5.

Schwartz, D., and Lazar, P. (1964). Elements de Statistique, pp. 120-125. Flammarion, Paris.

Van Slyke, D. D., and Neill, J. M. (1924). The administration of gases in blood and other solutions by vacuum extraction and manometric measurement. fournal of Biological Chemistry, 61, 523.

Visscher, M. B., and Johnson, J. A. (1953). The Fick principle: analysis of potential errors in its conventional application. Fournal of Applied Physiology, 5, 635.

Whitehill, M. R., Longcope, W. T., and Williams, R. (1939). Occurrence and significance of myocardial failure in acute hemorrhagic nephritis. Bulletin of the fohns Hopkins Hospital, 64, 83.

Wilson, C. (1967). The natural history of nephritis. In Renal Disease, and ed., pp. 225-251. Ed. by D. A. K. Black. Blackwell Scientific Publications, Oxford and Edinburgh.

Requests for reprints to Professor Kenan Binak, Taksim, Topcu Caddesi, Elbir Apt. 22/2, Istanbul, Turkey. 